\title{
LIMITATION OF TRADE MARGINS AS A MEASURE OF FOOD PRICE CONTROLS: EXPERIENCE OF SERBIA ${ }^{1}$
}

\author{
Snežana Radukič², Milan Marković
}

\begin{abstract}
Summary
The aim of this study is to examine the influence of trade margins limitations to the prices of basic food products and general price level in the Republic of Serbia. Assessing the effects of the Regulation on the margins limitations from 2012, this paper considers the purpose of applying this instrument of indirect price control. In practice, prescribing a maximum trade margins can have positive effects on the food market stability only in the short term. It is therefore necessary a broader consideration of the factors of pricing on the food market and food inflation regulation by economic policy measures. A particular problem is the low degree of competition in the trade sector, which significantly affects the prices of the final products. Food price movements are very unstable, while their share in the consumer price index in the Republic of Serbia is significantly. It is logical to conclude that food prices have a dominant influence on inflation, so that the government actions in this area are justified.
\end{abstract}

Key words: limitation of trade margins, control of food prices, inflation, trade sector, competition.

JEL: E31, E64, Q11, D40

\section{Introduction}

Price control by a government exists in all economies. It is introduced when policymakers believe that the market price of a good isn't fair to the buyers or sellers (Mankju, Tejlor, 2008). In modern economies the upper limit of prices is mainly controlled. This is because developing countries often face with inflation, which is a major economic disorder whose

1 The paper was prepared for the purpose of projects no. 44007 which is financed by the Ministry of Education and Science of the Republic of Serbia.

2 Snežana Radukić, Ph.D., Associate Professor, University of Niš, Faculty of Economics, Trg kralja Aleksandra Ujedinitelja no. 11, 18000 Niš, Serbia, Phone: +381 6414948 00, E-mail: snezana.radukic@eknfak.ni.ac.rs

3 Milan Marković, M.Sc., Ph.D. student and scholarship recipient from the Ministry of Education, Science and Technological Development of the Republic of Serbia, University of Niš, Faculty of Economics, Trg kralja Aleksandra Ujedinitelja no. 11, 18000 Niš, Serbia, Phone: +381 6428851 34, E-mail: markovicmilan89@gmail.com

EP 2015 (62) 1 (193-205) 
effects are reflected at the macro and micro level. From the microeconomic point of view, inflation directly causes a decline in the purchasing power of the population, while at the macro level leads to macroeconomic instability. To prevent this, governments have at their disposal various instruments and measures to control prices.

Prescribing the maximum and minimum prices is in the domain of direct price control. The aim of maximum prices is to protect consumers from excessive price increases, primarily when it comes to basic, essential goods whose prices significantly determine the general price level, such as following goods: bread, milk, oil, sugar, flour, etc. These prices are defined for a specific time period and can be corrected only after its expiration. In Serbia is still in effect the Regulation of bread price limitations (type "Sava") in order to protect the purchasing power of the lower social categories of the population (Uredba o obaveznoj proizvodnji i prometu hleba od brašna "T-500", 2012). Price level is determined in relation with the market situation and adjusted accordingly after a certain period of time. On the other hand, there is the practice of determining the minimum prices that protect the revenue of manufacturers. In particular, they are present within agriculture as the primary economic activity. In this case, the aim is to provide a decent standard of living for farmers in the case of a fall in market prices due to oversupply relative to demand. Many economists point out that the measures of direct price control could only solve problems in the short term. These measures are almost non-existent in the developed market economies. Therefore, in the economic practice of many economies is more frequent influence on prices by measures of indirect government regulation.

A significant number of products are influenced by direct and indirect price controls, and they are included in the calculation of the consumer price index, which suggests that government intervention is very important from the standpoint of preserving market stability. Indirect measures of price regulation include stockpiles, international trade policy measures, fiscal and monetary policy. They are instruments of economic policy which have the function of price stabilization. A special aspect of the indirect price control is adoption of positive legislation by the government, which determines the specific terms of trade of certain products. One of these instruments, which will be analyzed in this paper, is the Regulation of trade margins limitation at $10 \%$ for basic food products (hereinafter: the Regulation). In this way, the government regulates the relations in markets that are volatile and which largely causing an increase in the general price level. This protects the living standards of consumers, primarily those with lower incomes who spend relatively more on basic needs.

It is important to point out that limiting of trade margins can't directly affect prices. For example, an increase in purchase prices can lead to an increase in selling prices, even in cases of reducing the margin rate. Also, it should be noted that although the government intervention in the price area can have significant effects, the free operations in the market in the long run are in the basis of each economic policy (Stojanović, 2012). In the most market economies, the indirect measures of price controls are increasingly less applied. The dominant purpose becomes to attract and stimulate the entry of new competitors in the field of trade, including retail and wholesale. Only the competitive business environment can provide an adequate quality, prices and the rise in social 
welfare. Until the establishment of such a situation in the food market, the government will have to intervene in the trade sector to prevent the overflow of oligopoly prices on inflation, which threatens undermine the value of key macroeconomic indicators (balance of payments, exchange rate, standard of living).

\section{Methodology and data sources}

Food prices are a major factor in the rise of inflation in Serbia. Increase in food prices certainly, sooner or later, reflect in the inflation rise in the country (Gregorio, 2012). Their share in the consumer price index is about $34 \%$, based on the data of the Statistical Office of the Republic of Serbia. Also, the price volatility of agricultural products and foodstuffs is very important. It was described in the report of OECD (2011) and in the one of Wilson's works (2012). Therefore, the measures of price controls just bind most of the food market. Percentage limits trade margins, as well as products to which the percentage refers, are derived based on the Regulation in the Official Gazette of Republic of Serbia. The aim of this Regulation is to limit the rise in food prices as a result of the low level of competition in the food market (trade sector) in Serbia.

Firstly, we have analyzed the situation in the trade sector of the Republic of Serbia. Then, using the comparative method, we have presented researching results bearing in mind the official data. Finally, we have included some of the most important factors that have hindered the effect of the Regulation.

By using the data of the Ministry of Internal and External Trade and Telecommunications of the Republic of Serbia, which referred to prices of products that were covered by the Regulation, we come to know about food prices, as well as the effect of price control measures. Data analysis was conducted in the months that are important from the point estimates of the effects of the said Regulation (December 2011, January 2012, December 2012, and January 2013). By monitoring of changes in each of the product markets are derived conclusions about price trends and factors that contribute to it. It is also the main goal of this research.

\section{Features and degree of competition in the retail sector in Serbia}

The trade sector has "mediating function" and thus has decisive role in the pricing of the final food. On the other hand, the prices of food and non-alcoholic beverages in the consumer price index amounted to $34.52 \%$ (SORS, 2013). In the developed countries of Europe the percentage is almost twice smaller. From this, it can be concluded that the characteristics and specificities of pricing in the trade (and wider on food market) in Serbia have the large influence on the general price level in the national economy. Although contemporary governments rarely intervene in this area, there are specific situations in which they should operate from the viewpoint of the whole society. Monopolized markets are a striking example where it is badly needed government regulation in the field of prevention of price increases.

Contemporary markets are characterized by monopolistic and oligopolistic structures. This leads to a limitation of competition and inflationary tendencies due to excessive 
prices by sellers. In today's economic conditions, it is common cooperation among enterprises in the form of secret negotiations and agreements, so-called secret oligopoly. In this case, two or more companies set their prices, volumes, market shares or make common business decisions. Imperfect market structures exist in many industries. In them the dominant players abusing their position by raising the prices and thus causing adverse effects on the living standard of consumers and the status of other "minor" sellers. The increase in prices reduces the purchasing power of consumers, while sellers, because the better negotiating skills, are able to determine better procurement conditions at the expense of the suppliers (Stojanović et al., 2010).

Inflationary effects of oligopolies can be particularly manifested if this market structure occurs in the production and distribution of basic goods. This case is typical for Serbia, given the low level of competition in the sugar, milk and oil market. Processors and retailers often dictate terms to producers and in the market of final consumption can abuse their position because of the low level of competition. On this basis, it can be concluded that monopolies (pricing policy) don't threaten only the final consumers, but also primary producers by low purchase prices and the effects of an increase in the rate of inflation are obvious.

One of the main reasons for the adoption of the Regulation is precisely the existence of a low degree of competition in the retail sector, which is a key reason for the high price of the final products. In Serbia, there is a gradual enlargement of the retail chain stores. It is expected that the Croatian "Agrokor" will buy "Mercator" and, after taking over the "Roda", will increase market share, which could result in abuse of dominant position, and consequently cause price increase. In this case, there will be form classic duopoly ("Agrokor" and "Delhaize" as the dominant market participants), and instead of war by low prices (because oligopolies don't like this) it is possible to enter into a public or secret agreements. The negative fact is that there are a small number of companies in a wholesale. This oligopolistic situation is unfavourable from the point of primary producers. In such relationships, buyers (wholesale trading companies) can significantly affect the level of prices or the volume of purchases by mutual agreements. The data show that the margins in the wholesale are higher than those determined by commercial enterprises in retail, that further affecting the expression of higher consumer prices, and therefore of the general price level.

Stimulating of foreign investment in the trade sector creates competition in developing countries, where are oligopolies and monopolies. Competition and trade liberalization are the best "medicine" for a price reduction within each country. Since 2000, in the trade sector was entered many international trading companies, such as: "Metro", "Mercator", "Interex", "Idea", "Delhaize". In Serbia is a low saturation of the market, which may attract some foreign companies that are still undecided to start a business in Serbia. Some of the reasons for this may include: political risk, corruption, low purchasing power of the population, administrative barriers and business risk. All these factors adversely affect the attractiveness of the market and discourage potential investors to participate in the trade sector of our country. 


\section{Effects of the Regulation of trade margins limitation from 2012}

It can be seen that in the area of trading in Serbia is noticeable a low level of competition. Margins on individual products are much higher than in neighbouring countries. It can be said that trade is "responsible" for the manifestation of high food prices and overall inflation rate. It is therefore, in December 2011, the Government of the Republic of Serbia adopted the Regulation, which included limiting the overall rate of trade margin of $10 \%$ in the first half of 2012 (Uredba o posebnim uslovima prometa određene robe, 2011). While it is primarily planned that Regulation applies until the end of June, due to high inflation and, consequently, falling living standards of population, the Government decided to extend Regulation validity to the end of 2012. So, because it did not solve the initial problems, the Government has adopted a new Regulation on special trading conditions of certain goods (Uredba o posebnim uslovima prometa određene robe, 2012).

The measures of trade limiting are usually made for a period of no longer than six months, while in exceptional cases, there is a possible extension due to the weak effects of removing the initial cause. Constraints are usually introduced in the following situations: consumer protection, sudden changes or risk of large price changes, shortage of goods (primarily existential) for normal supply of population and economy and so on.

Products covered by the Regulation were: wheat flour (type 400 and type 500), eating sunflower oil, cow's milk (heat-treated), yogurt, sugar (white crystal), fresh meat (pork, beef and chicken) and freshwater fish. This act regulates the movement on the markets which most contribute to the rise in the inflation rate. In our country, there are the markets of main food products which are largely limited: oil, sugar and milk market. It is interesting to analyze the movement of prices of these products in the period before implementation, during implementation and after the abolition of the Regulation in the territory of the Republic of Serbia, as shown in the following table (Table 1).

Table 1. Comparative review of price movements of products covered by the Regulation of trade margins limitation in the period before implementation, during implementation and after its abolition

\begin{tabular}{|l|c|c|c|c|}
\hline \multirow{2}{*}{\multicolumn{1}{|c|}{ Products }} & \multicolumn{4}{c|}{ Product prices in the analyzed months } \\
\cline { 2 - 5 } & $\begin{array}{c}\text { December } \\
\mathbf{2 0 1 1}\end{array}$ & January 2012 & $\begin{array}{c}\text { December } \\
\mathbf{2 0 1 2}\end{array}$ & January 2013 \\
\hline Wheat flour (1 kg) & 56.08 & 45.68 & 54.90 & 55.73 \\
\hline Pork meat (1 kg) & 430.15 & 421.82 & 472.55 & 461.60 \\
\hline Chicken meat (1 kg) & 233.86 & 235.18 & 313.76 & 318.01 \\
\hline Eating oil (1 1) & 129.91 & 125.33 & 169.84 & 169.25 \\
\hline Milk (1 1) & 86.62 & 81.69 & 96.16 & 96.89 \\
\hline Yogurt (1 1) & 92.31 & 85.55 & 94.45 & 95.09 \\
\hline Sugar (1 kg) & 103.82 & 95.40 & 95.34 & 94.13 \\
\hline Freshwater fish $(1 \mathrm{~kg})$ & 683.56 & 669.72 & 777.29 & 792.35 \\
\hline
\end{tabular}

Source: Authors' systematization on the basis of data of Ministry of Internal and External Trade and Telecommunications of the Republic of Serbia, 2013. 
On the basis of Table 1, in Table 2 is shown a percentage change in prices in the first month of implementation of the Regulation. From Table 2 it can be seen a decrease in prices of almost all products covered by the Regulation at the beginning of its implementation. Only the price of chicken meat is slightly increased. This means that retail margins were greater than $10 \%$ for basic food products before the adoption of this Government Regulation.

The data shows that margins were more than $20 \%$ for some food products (Lovreta, 2008). To prove it, a classic example is the promotional prices of certain products (for example, coffee). Its price is often lowered by up to $15 \%$ of the original (regular) price. High rates of margin aren't the result only of a lack of competition, but also a consequence of compensation of higher business costs because of the influence of many factors (drought, floods, rising of oil price). These factors are present in developed countries too, where the increase in food prices is a big problem. In Serbia, the high rate of margins in the retail is consequence not only of high market power of the participants, but also of higher margins in wholesale, which is a crucial factor for the higher trade margins in retail.

In the short term, the implementation of the Regulation has reduced the prices of almost all products whose prices are subject to analysis, so that its positive effects are felt immediately after the adoption.

Table 2. Percentage change in prices in the first month of the implementation of the Regulation

\begin{tabular}{|l|c|c|c|}
\hline \multicolumn{1}{|c|}{ Products } & $\begin{array}{c}\text { Prices in December } \\
\mathbf{2 0 1 1}\end{array}$ & $\begin{array}{c}\text { Prices in January } \\
\mathbf{2 0 1 2}\end{array}$ & $\begin{array}{c}\text { The rate of price } \\
\text { change }\end{array}$ \\
\hline Wheat flour $(1 \mathrm{~kg})$ & 56.08 & 45.68 & $-18,54$ \\
\hline Pork meat $(1 \mathrm{~kg})$ & 430.15 & 421.82 & $-1,94$ \\
\hline Chicken meat $(1 \mathrm{~kg})$ & 233.86 & 235.18 & $+0,56$ \\
\hline Eating oil $(1 \mathrm{l})$ & 129.91 & 125.33 & $-3,53$ \\
\hline Milk (1 1) & 86.62 & 81.69 & $-5,69$ \\
\hline Yogurt $(1 \mathrm{l})$ & 92.31 & 85.55 & $-7,32$ \\
\hline Sugar $(1 \mathrm{~kg})$ & 103.82 & 95.40 & $-8,11$ \\
\hline Freshwater fish $(1 \mathrm{~kg})$ & 683.56 & 669.72 & $-2,02$ \\
\hline
\end{tabular}

Source: Authors' systematization on the basis of data of Ministry of Internal and External Trade and Telecommunications of the Republic of Serbia, 2013.

Increase the value of the basket of products is caused by the increase in prices of products covered by the Regulation, as well as other products in the group of food and non-alcoholic drinks. Value of the basket of goods was increasing continuously from month to month in the year when the Regulation was in force. The positive effects of the slower growth in prices of basic food products have disappeared because of circumstances and factors that affected food prices. 
Table 3. Values of the category of food and non-alcoholic drinks and products covered by the Regulation

\begin{tabular}{|l|c|c|c|c|}
\hline \multirow{2}{*}{\begin{tabular}{|} 
Category of products \\
\cline { 2 - 5 }
\end{tabular}} & \multicolumn{4}{|c|}{ The value of the product category in the certain month } \\
of the year
\end{tabular}

Source: Authors' calculation on the basis of data of Ministry of Internal and External Trade and Telecommunications of the Republic of Serbia, 2013.

Price movements were caused by other determinants that affect the food prices (exchange rate, inflation expectations, import costs, agricultural season and adverse weather conditions). Data on monthly rates of increase in prices located within Table 4. In September and October of 2012, despite the limitation of margins was a growth in consumer prices of $5.1 \%$. In just two months, prices are increased as in developed countries for two or three year. Because of poor agricultural season (July and August), there was an increase in food prices due to shortages of goods. Effect of price increase of the raw food on final food products is delayed due to the time needed for processing of the primary products, as well as because of the use of food reserves from the previous period. Prices of raw foods (fruits, vegetables, eggs) increased by $24 \%$ and processed foods for $10.9 \%$, while the overall increase in prices of food and non-alcoholic drinks in 2012 amounted to 15.4\% (Ministry of Internal and External Trade and Telecommunications of the Republic of Serbia, 2013a).

The overall rate of inflation is very sensitive to changes in price of this product category in the consumer basket, because food has the largest contribution to the total current rise in consumer prices (Milanović et al., 2011). The rise in prices of alcoholic drinks and tobacco was highest (31.7\%), but the contribution to inflation, due to a lower share of the consumer price index was only about 1.7 percentage points. The contribution to the rise in food prices to overall inflation rate was 6 percentage points (Ministry of Internal and External Trade and Telecommunications of the Republic of Serbia, 2013a). During this period, the share of food and non-alcoholic drinks in the structure of the consumer price index was $38.8 \%$.

The increase in Value Added Taxes (VAT), and especially excises, in October, had an impact on food prices, because in food production (raw and processed both) costs of energy have significant share. The rise in prices of petroleum products (excise goods) was mainly influenced on the increase in consumer prices in October. High dependence on imports of energy also increases production costs in conditions of an increase in the exchange rate, which is also been manifested in mid of 2012. One study precisely analyzes the effects of the two market factors: prices of energy and agricultural commodities and exchange rate on food prices (Baek, Koo, 2010). From the Table 4 it is clear that the increase in food prices (during the autumn) had dominant influence on a monthly and later on the overall rate of inflation in the year. 
Table 4. Monthly price growth rates in 2012

\begin{tabular}{|c|c|c|c|c|c|c|c|c|c|c|c|}
\hline \multicolumn{10}{|c|}{ Consumer prices growth rates by months in 2012 (in \%) } \\
\hline I & II & III & IV & V & VI & VII & VIII & IX & X & XI & XII \\
\hline 0.1 & 0.8 & 1.1 & 0.6 & 1.4 & 1.1 & 0.1 & 1.6 & 2.3 & 2.8 & 0.0 & -0.4 \\
\hline
\end{tabular}

Source: Authors' systematization on the basis of data of Ministry of Internal and External Trade and Telecommunications of the Republic of Serbia, 2013.

During the 2012, there was a constant growth of the value of consumer basket and prices that are controlled by the government, i.e. the competent Ministry. Of course, it is not the role of government to fix prices, but it is imperative to achieve price stability in certain situations, which is important for the whole society. Because of the extremely unfavourable agricultural season, depreciation of the national currency and the unstable political situation, in order to prevent overflow of food prices, the government has used the system of stockpiles.

Food prices were directed in the desired direction by the stockpiles, in order to ensure macroeconomic stability and prevent overflow of food prices to inflation. Stockpiles include just the essential products: oil, sugar, meat, and inputs that are used for the smooth operation of the agricultural production. This prevents that rise in prices of these products affect significant increase in the general price level within the national economy. In order to stabilize the market in September, the government has decided to interventional selling 5 million litters of eating sunflower oil and 5 million kilos of sugar. The retail price of oil amounted to 142.56 RSD, while the price of sugar was 95.05 RSD (Ministry of Internal and External Trade and Telecommunications of the Republic of Serbia, 2013a). Serbian Government intervened with additional measures which aim was to help primary producers to freely continue with their production process (sales of raw materials (corn, wheat) for agricultural production at much lower prices).

Analyzing the rate of prices increases (January of 2014 compared to December of 2012) from Graph 1, it can be seen that the sugar market was stable, although there were problems at the end of the summer in the form of shortages on the shelves of retail stores. The price of sugar is even reduced due to Regulation and stockpiles. Prices of flour and yogurt were almost constant as well as a price of sugar. But, on the other side, there were significant market distortions in the market of eating sunflower oil. Oil price in the short term is increased by over $30 \%$. Interventional sale of oil was only partially mitigating this increase in price due to rising of sunflower price because of bad weather conditions. Therefore, in October 2012, the government adopted Regulation amending the validity of the Regulation, which is the overall margin rate on eating sunflower oil further reduced to only $5 \%$ (Uredba o izmeni Uredbe o posebnim uslovima prometa određene robe, 2012). By the end of the year, the price of oil has stabilized. Regarding the price of the meat, particularly chicken, there has also been a significant growth. The key reason was the lack of fodder due to severe droughts in the summer, which was one of the warmest in recent years, and with very little rainfall. For this example, it can be seen that the market of agricultural produces is the major determinant of the food market stability. 
Graph 1. Price increase (January 2013 - December 2011), in \%

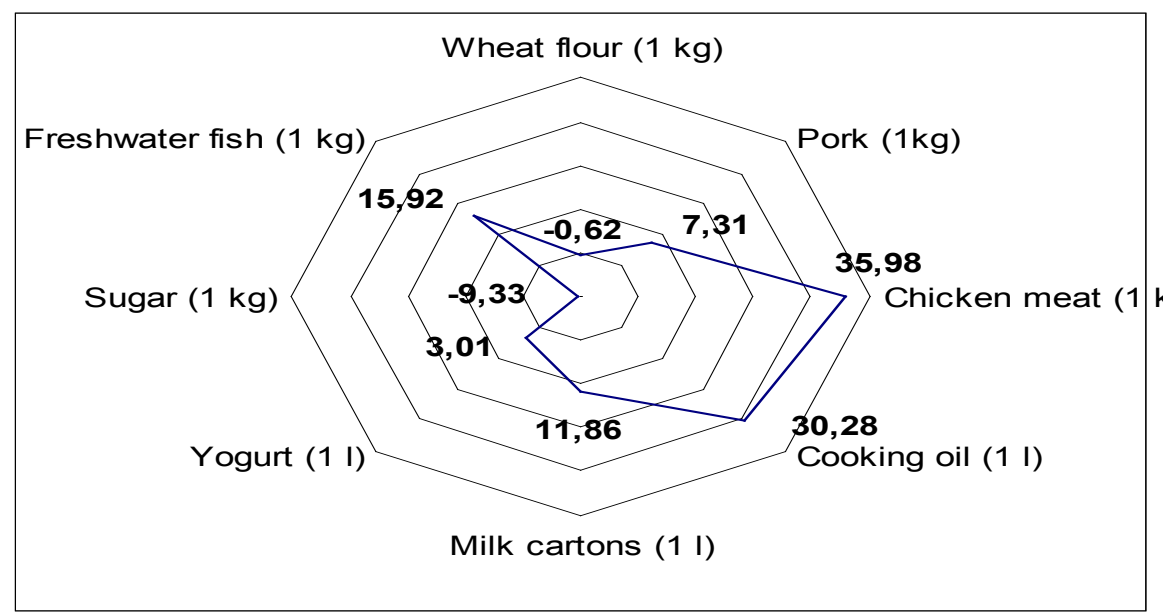

Source: Authors' calculation on the basis of data of Ministry of Internal and External Trade and Telecommunications of the Republic of Serbia, 2013.

After the completion of the implementation of the Regulation has been no major change in the price of these products. One of the main reasons is the stability of the exchange rate during this period (due to more restrictive monetary policy), constant prices of oil and petroleum products, as well as a fall in aggregate demand (NBS, 2012). Djukić and associates (2009) concluded that monetary policy is also an important factor limiting the effects of rising prices of food products on inflation.

\section{Factors that limited the positive effects of the Regulation}

Now let's see some of the factors that have prevented the expression of the positive effects of the Regulation. Climatic conditions in 2012 are almost halved crop of some primary products. The movement of world prices of agricultural products has also had an impact on the annual inflation rate. The high inflation rate of $12.2 \%$ in 2012 exhibited due to the low base (starting base) in the previous year. It is the largest increase in the general price level since adopting the consumer price index. In order to reduce the high budget deficit, in the second half of 2012 was made decision to increase the general rate of VAT. Even though the special tax rate hasn't changed, there has been some increase in prices of imported inputs (raw materials), which is indirectly reflected in the rise in prices. Given the strong correlation between the exchange rate and inflation, increase in exchange rate of nearly $9 \%$ in 2012, strongly defines the general price level due to the high import dependence on raw materials and energy, which have a significant share in the structure of production costs.

Monopolistic and oligopolistic market tendencies have caused the inefficiency of measures of state intervention in preventing inflation. These market situations are typical for developing countries that have underdeveloped market (Milanović et al., 2009). The low level of competition creates an enabling environment for increasing prices by sellers. If such situation is linked to the food market, there is a manifestation of the rapid increase 
in the general price level. It is therefore important competition policy, which should be controlled and sanctioned the creation of monopolistic structure on the market, in order to prevent spill over of growth prices on inflation. The aim of competition policy is to prevent the dictation of prices by a monopolists or their dominant influence in the country with narrow and underdeveloped markets.

By eliminating the possibility of agreement between the major sellers, the state is fighting against monopolization of the market, restricting competition and spill overs of increase of monopoly prices to inflation. Competition policy is the government's measure of indirect price controls. Increasing competition affects the decrease in the product price, but also leads to an increase in social welfare. According to the list of the World Economic Forum, Serbia is among the countries with the highest impact of monopolies and cartels. This is the main reason why our country year after year recorded the highest inflation rates in the region.

Trade margins restriction had some negative implications. The Regulation caused negative effects on small traders, whose business is largely dependent on the sale of basic food products (Stojanović et al., 2012). Thus, a large number of smaller shops were forced to suspend its business or to realize the loss due to lack of income, so that it came to a further weakening of competition in the market. It is estimated that each year averaged two to three thousand small shops were closed because of the high costs and competition from large retail chains. They only survive in those market segments which are not covered by the "big stores" or where the most important factor for consumers, when they make purchase decisions, is market nearness.

However, there is an undeniable need for indirect price controls, which ensures the stability of food markets. Price volatility is a big problem in the short term and the impact of season is very important (Berument, Sahin, 2010). So, reaction of government is justified. In the long term it is necessary to significantly invest in agriculture to which the food industry and trade sector are multiply connected. Restricting of trade margins can prevent short-term negative price fluctuations over the sacrifice of profit by traders. But it is necessary to consider the problems faced by farmers and processors. In the food industry, the future courses of action must be: increasing competition, limiting the impact of a better bargaining position in relation to producers, strengthening the process of association of manufacturers and linking farmers for equality in bargaining.

\section{Conclusion}

Agriculture is usually highly dependent on natural factors, which initiates the need for government intervention in the regulation of markets of agricultural and food products. Limitation of retail margins for basic food products at $10 \%$ yielded some results in limiting the rise in prices at the beginning of its application. Prices of agricultural and food products are very unstable and short-term stabilization is necessary from the standpoint of preventing market disruptions and ensuring stability of prices. There are some objective factors which limited the effect of the Regulation. First, unfavorable climatic conditions have almost halved crop of certain products. Second, high inflation exhibited due to the low starting 
base. Due to these facts, a stable exchange rate hasn't helped to decrease in product prices for consumer. This is because of present oligopoly trends in the food market in the country. Some measures of foreign trade policy have just alleviated inflation, such as the ban on exports and emergency imports from abroad. Growth in import costs (energy costs) due to the depreciation of the national currency had affected the increase in food prices, despite the trade margin limitations. There is a perception that, for the duration of the Regulation, the producers have raised prices, traders gave a higher rebate, which counteracts the effects of limiting margins on basic food products and affect the general price level.

Regulation has had a double effect: preventing market distortions and regular supply of basic food products. In addition, price controls protects the most vulnerable segments of the population from rising prices of the basic goods, but also prevents higher inflation distortions in the economy. Despite the limitation of margins, prices couldn't be held at a stable level due to the increase in producer (purchase) prices. Although margins are the same in relative terms, as they apply to producer prices, they grew in absolute terms and also are a factor of retail prices growth. Purchase prices were rising, bearing in mind the significant rise in oil prices on the world market, the depreciation of the national currency (increase in the exchange rate) and increase in prices of imported inputs (raw materials) used in production.

Regulation of retail margin imitations for basic foods at $10 \%$ didn't produce some great results in preventing price increases. Therefore, this act can only be support means to overcome the problem in the short term. Increasing competition in the food market and trade liberalization are possible ways of regulating inflationary disorders and preserving purchasing power of population.

\section{Literature}

1. Baek, J., Koo, W. (2010): Analyzing Factors Affecting U.S. Food Price Inflation, Canadian Journal of Agricultural Economics, vol. 58, pp. 303-320.

2. Berument, M. H., Sahin, A. (2010): Seasonality in Inflation Volatility: Evidence from Turkey, Journal of Applied Economics, vol. 13, no. 1, pp. 39-65.

3. Djukić, M., Pješčić, V., Vilaret, S. (2009): Kretanje cena poljoprivrednih proizvoda i reakcija monetarne politike, Ekonomika poljoprivrede, vol. 56, no. 3, pp. 469-479, IEP Beograd, Srbija.

4. Gregorio, J. (2012): Commodity Prices, Monetary Policy, and Inflation, IMF Economic Review, vol. 60, no. 4, pp. 600-633, IMF, Washington.

5. Lovreta, S. (2008): Strategija i politika razvoja trgovine Republike Srbije, Ekonomski fakultet i Ministarstvo trgovine i usluga Republike Srbije, Beograd, Srbija, available at: www.seda.org.rs/download/strategija_i_politika_razvoja_trgovine.pdf

6. Mankju, G. N., Tejlor, R. M. (2008): Ekonomija, Data status, Beograd, Srbija. 
7. Milanović, M., Ljubić, M., Muminović, S. (2011): Uticaj cena hrane na ciljanu inflaciju u Republici Srbiji, Ekonomika poljoprivrede, vol. 58, no. 4, pp. 547-562, IEP Beograd, Srbija.

8. Milanović, M., Mihailović, B., Paraušić, V. (2009): Elementi konkurencije i strukturne tipologije agrarnog tržišta u Srbiji, Ekonomika poljoprivrede, vol. 56, no. 4, pp. 519534, IEP Beograd, Srbija.

9. Ministry of Internal and External Trade and Telecommunications of the Republic of Serbia (2013): Potrošačka korpa, Belgrade, Serbia, available at: http://razvoj.mtt.gov. rs/informacije/potrosacka-korpa/

10. Ministry of Internal and External Trade and Telecommunications of the Republic of Serbia (2013a): INFORMACIJA o ostvarenom rastu potrošačkih cena u periodu januar - decembar 2012. godine, Belgrade, Serbia, available at: http://mtt.gov.rs/ download/rast-potrosackih-cena/potrosackecene_01-12 2012.pdf

11. Narodna banka Srbije (NBS), (2012): Izveštaj o inflaciji, available at: www.nbs.rs/

12.OECD (2011): Price Volatility in Food and Agricultural Markets: Policy Responses, Policy Report including contributions by FAO, IFAD, IMF, OECD, UNCTAD, WFP, the World Bank, the WTO, IFPRI and the UN HLTF, available at: http://www. oecd.org/dataoecd/40/34/48152638.pdf

13. Statistical Office of the Republic of Serbia (SORS), (2013): Indeksi potrošačkih cena u Republici Srbiji, novembar 2013, Belgrade, Serbia, available at: http://webrzs.stat.gov. rs/WebSite/repository/documents/00/01/23/23/cn11122013.pdf

14. Stojanović, B. (2012): Mikroekonomija, Ekonomski fakultet, Niš, Srbija.

15. Stojanović, B., Radivojević, V., Stanišić, T. (2012): Institucionalne pretpostavke efikasnosti politike zaštite konkurencije, Ekonomski horizonti, vol. 14, no. 2, pp. 121131, Ekonomski fakultet, Kragujevac, Srbija.

16. Stojanović, B., Stanišić, T., Veličković, M. (2010): Problem zaštite konkurencije u trgovini na malo u Srbiji, Škola biznisa, vol. 7, no. 3, pp. 57-66, Visoka poslovna škola strukovnih studija, Novi Sad, Srbija.

17. Uredba o posebnim uslovima prometa određene robe, Official Gazette of Republic of Serbia, no. 102/2011.

18. Uredba o posebnim uslovima prometa određene robe, Official Gazette of Republic of Serbia, no. 63/2012.

19. Uredba o obaveznoj proizvodnji i prometu hleba od brašna T-500 “, Official Gazette of Republic of Serbia, no. 94/2012.

20. Uredba o izmeni Uredbe o posebnim uslovima prometa određene robe, Official Gazette of Republic of Serbia, no. 100/2012.

21.Wilson, N. (2012): Discussion: Causes of Agricultural and Food Price Inflation and Volatility, Journal of Agricultural and Applied Economics, vol. 44, no. 3, pp. 423-425. 


\title{
OGRANIČENJE TRGOVAČKIH MARŽI KAO MERA KONTROLE CENA HRANE: ISKUSTVO IZ SRBIJE
}

\author{
Snežana Radukič ${ }^{4}$, Milan Markovićc
}

\section{Rezime}

Cilj ovog istraživanja jeste da se sagleda uticaj ograničenja trgovačkih marži na cene osnovnih prehrambenih proizvoda i opšti nivo cena u Republici Srbiji. Procenjujući efekte Uredbe o ograničenju marži iz 2012. godine, u radu se razmatra svrsishodnost primene ovog instrumenta posredne kontrole cena. Rezultati pokazuju da propisivanje maksimalnih marži u trgovini može imati pozitivna dejstva na stabilnost tržišta hrane samo na kratak rok. Ističe se neophodnost šireg sagledavanja faktora formiranja cena na tržištu hrane i potreba da se ostalim merama državne regulacije utiče na inflaciju. Poseban problem predstavlja to što sektor trgovine, koji značajno utiče na cene finalnih proizvoda, karakteriše nizak stepen konkurencije. Kretanje cena hrane je veoma nestabilno, dok je njihovo učešće u indeksu potrošačkih cena u Republici Srbiji značajno. Nameće se logičan zaključak da cene prehrambenih proizvoda imaju dominantan uticaj na kretanje inflacije, tako da je delovanje države u ovoj oblasti opravdano.

Ključne reči: ograničenje trgovačkih marži, kontrola cena hrane, inflacija, sektor trgovine, konkurencija.

4 Dr Snežana Radukić, doktor ekonomskih nauka, vanredni profesor, Univerzitet u Nišu, Ekonomski fakultet, Trg kralja Aleksandra Ujedinitelja 11, 18000 Niš, Srbija, Telefon: +381 6414948 00, E-mail: snezana.radukic@eknfak.ni.ac.rs

5 Milan Marković, M.A., student doktorskih studija i stipendista Ministarstva prosvete, nauke i tehnološkog razvoja Republike Srbije, Univerzitet u Nišu, Ekonomski fakultet, Trg kralja Aleksandra Ujedinitelja 11, 18000 Niš, Srbija, Telefon: +381 6428851 34, E-mail: markovicmilan89@gmail.com

EP 2015 (62) 1 (193-205) 